\title{
KONSEP CIPTAAN BARU N.T. WRIGHT SEBAGAI PARADIGMA TEOLOGI PUBLIK KAUM INJILI DI INDONESIA*
}

\author{
Febrianto**
}

\begin{abstract}
Abstrak: Pancasila adalah falsafah hidup yang menaungi kehidupan berbangsa dan bernegara di Indonesia. Falsafah ini tidak lepas dari kemajemukan yang menjadi sebuah realitas identitas bangsa Indonesia. Namun sejarah menunjukkan ruang publik Indonesia diwarnai konflik-konflik antar agama. Dalam menyikapi masalah ini, ada dua praksis yang umumnya menjadi reaksi orang Kristen di Indonesia. Respons yang pertama adalah praksis yang menekankan pentingnya dialog dan kehidupan bersama, namun cenderung mengabaikan pemberitaan Injil. Sedangkan respons yang kedua adalah reaksi yang cenderung menarik dan menutup diri. Dalam makalah ini, penulis mencoba memberikan proposal teologi publik injili menggunakan konsep ciptaan baru menurut N.T. Wright sebagai landasan praksis hidup kaum injili di Indonesia. Berporos pada kematian dan kebangkitan Kristus, Wright melihat bahwa karya Kristus membawa pengharapan eskatologis dunia hadir pada masa kini. Kisah tentang karya keselamatan ini adalah kisah Allah di ruang publik. Model yang dibangun Wright berfokus pada cara hidup orang Kristen mula-mula yang mempertontonkan Injil pengharapan itu di hadapan publik yang menggenapkan pengharapan dunia yang sedang jatuh dalam dosa. Dengan demikian, orang percaya yang sudah dipersatukan dalam kematian dan kebangkitan Kristus dipanggil untuk menjadi agen kerajaan Allah yang membawa kisah itu lewat hidupnya di ruang publik.
\end{abstract}

Kata-kata Kunci: Teologi publik, ruang publik, injili, Pancasila, Indonesia, ciptaan baru, N.T. Wright.

* Paper ini adalah juara pertama Lomba Karya Tulis Teologi (LKTT) tahun 2017 yang diselenggarakan STT Amanat Agung.

** Penulis adalah mahasiswa STT SAAT, Malang. Penulis dapat dihubungi melalui email: febri_12@hotmail.com. 


\section{Pendahuluan}

Sebagai bangsa dengan kemajemukan sebagai identitasnya, Indonesia dipersatukan oleh Pancasila yang menjadi "agama sipil" atau "agama publik." ${ }^{1}$ Pancasila sebagai "agama sipil" berarti bahwa di tengah keragaman identitas yang ada (suku, agama, dan ras), Pancasila adalah falsafah hidup yang mendasari kehidupan bersama di tengah keragaman tersebut. Dalam konteks agama, para pendiri bangsa memiliki cita-cita agar Pancasila menjadi pemersatu setiap pemeluk agama di tengah eksklusivitas tiap agama. Selain itu, berbeda dari sekularisme Barat, Pancasila justru memungkinkan setiap agama memiliki peran di ruang publik tanpa memandang mayoritas dan minoritas. ${ }^{2}$

Namun, cita-cita Pancasila yang sudah digaungkan lebih dari 70 tahun yang lalu masih sulit tercapai karena konflik-konflik yang mengatasnamakan agama di negara Pancasila ini. J.B. Banawiratma menyebutkan bahwa pada 1995-1997 telah terjadi puncak kekerasan kolektif yang melibatkan agama. ${ }^{3}$ Dalam kasus yang melibatkan orang

1. Benyamin F. Intan, "'Public Religion' and the Pancasila-Based State of Indonesia: A Theological-Ethical Analysis," Verbum Christi 1 no. 1 (April 2014): 31.

2. Intan, "'Public Religion' and the Pancasila-Based State of Indonesia," 31. Ruang publik yang dimaksudkan adalah dimensi-dimensi kehidupan di luar gereja di mana orang Kristen bisa berinteraksi dengan orang-orang dari berbagai identitas (politik, dialog antar agama, suku, dan sebagainya).

3. "On 9 June 1996 ten churches in the East Java harbour town of Surabaya were seriously damaged or totally destroyed. 10 October 1996 not less than 23 churches and schools were destroyed in a planned and orchestrated action in the East Javanese town of Situbondo. 26 December 
Kristen, penelitian FKKI (Forum Komunikasi Kristen Indonesia) menunjukkan bahwa jumlah pembakaran gereja pada tahun 19961997 mencapai 105 gereja. ${ }^{4}$ Ruang publik Indonesia pun diwarnai oleh sejarah konflik-konflik antar agama yang masih membekas hingga kini.

Fakta-fakta di atas senada dengan penelitian Binsar Hutabarat dan Hans Panjaitan pada Februari-Maret 2016 mengenai tingkat toleransi antar agama di Indonesia. Mereka mendapati bahwa Indonesia berada pada indeks 3,89 dari 6 dalam hal toleransi antar umat beragama. Angka ini sebetulnya menunjukkan bahwa sampai saat ini pun konflik antar agama di Indonesia yang tergolong toleran dan demokratis masih tergolong cukup tinggi (lebih dari 50\%). ${ }^{5}$ Budaya konflik ini sudah begitu melekat di dalam kehidupan sosial masyarakat Indonesia yang majemuk.

Gereja sebagai bagian dari bangsa pun secara teologis maupun praktis bergumul dengan ruang publik Indonesia yang seperti ini. Memang orang Kristen di Indonesia berada dalam posisi

1996 very serious riots took place in Tasikmalaya, Western Java, in many aspects resembling the Situbondo events" (J.B. Banawiratma, "The Fragile Harmony of Religions in Indonesia," Exchange 27 no. 4 [Oktober 1998]: 360).

4. Eka Darmaputera, "Pancasila Sebagai Satu-satunya Asas dalam Kehidupan Bermasyarakat, Berbangsa dan Bernegara: Sebuah Evaluasi Ulang," dalam Agama-agama Memasuki Milenium Ketiga, ed. Martin L. Sinaga (Jakarta: Gramedia, 2000), 148.

5. Hutabarat, Binsar A. dan H. Hans Panjaitan. "Tingkat Toleransi Antaragama di Masyarakat Indonesia." Societas Dei 3 no. 1 (April 2016): 2324. Penelitian ini dilakukan pada 5 organisasi kemahasiswaan berbasis agama, seperti GMKI, HIKMAHBUDHI, HMI, KMHDI, dan PMKRI. 
dilematis. Ada yang lebih suka membuka diri, mengambil jalan dialog demi kebaikan bersama, namun mandat untuk menginjili dikerdilkan dan diredam. ${ }^{6}$ Sebaliknya, ada juga yang lebih suka tinggal di dalam ghetto, mengurung diri dari dunia sehingga tidak peka terhadap mandat sosial di sekitarnya. ${ }^{7}$

Jikalau demikian, bagaimana seharusnya umat Kristen, terkhusus kaum injili, menjalankan praksis hidupnya di ruang publik dalam kultur religius bangsa seperti ini? Makalah ini ingin mencoba memberikan landasan teologis bagi praksis kaum injili di Indonesia. Tesis penulis adalah kematian dan kebangkitan Kristus menggenapi pengharapan tentang langit dan bumi yang baru. Karya Yesus menunjukkan bahwa pengharapan eskatologis pada masa yang akan datang itu sudah hadir pada masa kini. Kisah karya keselamatan Allah menunjukkan bahwa kisah ini adalah sebuah deklarasi publik yang menyatakan bahwa Allah sedang merestorasi seluruh dunia. Dengan demikian, setiap praksis dalam kehidupan umat Kristen adalah sebuah antisipasi yang mewartakan kerajaan Allah di bumi. Makalah ini akan disusun menjadi tiga bagian. Pertama, penulis akan memaparkan terlebih dahulu apa yang dimaksud dengan teologi publik serta apa yang membuat teologi publik memiliki corak injili. Kedua, penulis akan membangun konstruksi teologi publik di atas

6. Lih. Joas Adiprasetya, Mencari Dasar Bersama: Etik Global dalam Kajian Postmodernisme dan Pluralisme Agama (Jakarta: BPK Gunung Mulia, 2002), 147-48.

7. A. A. Yewangoe, Tidak Ada Ghetto: Gereja di dalam Dunia (Jakarta: BPK Gunung Mulia, 2009), viii. 
konsep ciptaan baru yang dikembangkan oleh Nicholas Thomas Wright (N.T. Wright). Terakhir, penulis akan memberikan beberapa usulan praksis dari pemaknaan terhadap landasan teologi publik yang sudah dibangun.

\section{Teologi Publik Injili: Mungkinkah?}

Teologi publik memang menjadi salah satu cabang ilmu teologi yang cukup baru dan banyak dikembangkan dalam beberapa dekade belakangan. ${ }^{8}$ Kendati memiliki spektrum yang cukup luas dan beririsan dengan bidang lain seperti teologi politik, teologi publik dapat didefinisikan sebagai lingkup ilmu teologi yang berfokus pada diskursus-diskursus yang menjawab isu-isu di ruang publik. ${ }^{9}$ Teologi publik mengafirmasi natur "publik" yang ada dalam teologi sebagai sebuah keniscayaan. Ini berarti teologi selalu memiliki dampak bukan hanya bagi gereja tetapi bagi ruang publik. ${ }^{10}$

Jika diskursus-diskursus teologis Kristen untuk menjawab isu di ruang publik ini bergantung secara unik pada aras teologi tertentu,

8. Felipe Gustavo Koch Buttelli, "Public Theology as Theology on Kairos: The South African Kairos Document as a Model of Public Theology," Journal of Theology for Southern Africa 143 (Juli 2012): 90. Sampai saat ini, teologi publik sudah berkembang menjadi berbagai bentuk (lih. Eneida Jacobsen, "Models of Public Theology," International Journal of Public Theology 6 [2012]: 7-8).

9. E. Harold Breitenberg Jr., "What Is Public Theology?" dalam Public Theology for a Global Society: Essays in Honor of Max L. Stackhouse, ed. Deirdre King Hainsworth dan Scott R. Paeth (Grand Rapids: Eerdmans, 2010), 5.

10. Júlio Paulo Tavares Zabatiero, "From Sacristy to the Public Square: The Public Character of Theology," International Journal of Public Theology 6 (2012): 56. 
maka teologi publik seperti apakah yang dapat dikatakan sebagai teologi publik injili? ${ }^{11}$ Jika identitas kaum injili adalah pengakuan terhadap finalitas Kristus dan Alkitab sebagai sumber otoritas tertinggi, bagaimana Alkitab sendiri menjawab isu-isu di ruang publik? Selama ini teologi publik injili dianggap belum banyak berkembang karena pergerakan injili sendiri pada awalnya banyak dipimpin oleh tokoh-tokoh penginjil dan pengkhotbah besar yang berfokus pada keselamatan jiwa secara individual. Misi kaum injili yang mengemban Amanat Agung pun seringkali dianggap dapat secara langsung menyelesaikan masalah-masalah sosial selama seseorang bertobat dari dosanya secara pribadi tanpa melihat bagaimana keselamatan dan isu sosial saling berkorelasi. ${ }^{12}$ Dalam konteks ini, penulis melihat bahwa teologi dari atas (theology from above) dan teologi dari bawah (theology from below) selalu dipertentangkan. Teologi yang dibangun kerap dianggap hanya berhenti di menara gading tanpa masuk ke akar rumput. Craig

11. Walaupun identitas injili memiliki keberagaman, namun secara umum gerakan injili atau evangelikalisme dicirikan oleh pengakuan terhadap aspek-aspek penting: (1) Alkitab sebagai firman Allah yang memiliki otoritas tertinggi; (2) penekanan pada konversi/pertobatan; (3) penebusan dosa melalui Yesus Kristus sebagai satu-satunya Tuhan dan Juruselamat (lih. J. I. Packer dan Thomas Oden, Satu Iman: Konsensus Injili [Jakarta: BPK Gunung Mulia, 2011], 9-11).

12. J. Budziszewski, "Evangelicals in the Public Square," dalam Evangelicals in the Public Square: Four Formative Voices on Political Thought and Action, ed. J. Budziszewski (Grand Rapids: Baker, 2006), 16-17. 
Bartholomew sendiri mengakui hal ini terjadi dalam lingkaran injili. la berkata: ${ }^{13}$

Within other Christian circles and in the evangelical tradition, this commitment [uniqueness, sufficiency, and finality of Jesus Christ] has been maintained, but far too often with a loss of the comprehensive, creation-wide, public dimensions of the faith, with the result that Jesus is affirmed as savior but hardly as savior of the world. This is what we call the "privatization of religion," in which freedom of religion is tolerated within the private sphere of our lives but kept out of the major public spheres of life.

Akan tetapi, ini bukan berarti bahwa tidak ada orang dalam lingkaran injili sendiri mengembangkan teologi publik. Tentu namanama seperti C.F.H. Henry, Abraham Kuyper, maupun Francis Schaeffer tidak dapat diabaikan. ${ }^{14}$ Belum lagi, gerakan Lausanne yang menjadi forum injili sedunia menjadi kebangunan injili dalam memikirkan ulang misinya dalam beberapa dekade belakangan. Sumbangsih-sumbangsih yang selama ini sudah ditunjukkan justru ingin menunjukkan kecukupan firman Allah dalam menjawab isu-isu di ruang publik. Justru Injil itulah yang menjadi bahan bakar yang memungkinkan seorang injili untuk masuk dan mentransformasi

13. Craig G. Bartholomew, Excellent Preaching: Proclaiming the Gospel in Its Context \& Ours (Bellingham: Lexham, 2015), 3. Walaupun Bartholomew sendiri banyak berbicara dalam konteks injili di negara Barat, penulis melihat argumen Bartholomew cukup dapat mewakili kaum injili di Indonesia secara umum.

14. J. Budziszewski, "Four Shapers of Evangelical Political Thought," 39. 
ruang publik. Jika demikian, maka teologi publik injili seharusnya dibangun di atas landasan teologi biblika yang serius sekaligus mampu membangun jembatan dengan ruang publik. ${ }^{15}$ Teologi publik yang injili harus mampu membawa ketuhanan, keunikan, partikularitas, maupun finalitas Kristus untuk berbicara bukan hanya bagi orang percaya, tetapi bagi dunia. ${ }^{16}$

\section{Ketika Surga Ada di Bumi: Ciptaan Baru sebagai Teologi Publik}

Nicholas Thomas Wright (N.T. Wright) adalah seorang sarjana Perjanjian Baru dari gereja Anglikan di Inggris. Sebagai penulis yang cukup produktif, Wright dikenal luas sebagai salah satu tokoh yang mengemukakan pandangan "New Perspective on Paul" dalam studi surat-surat Paulus. Tidak hanya itu, sumbangsih besar Wright juga ia tunjukkan sebagai seorang sejarawan yang membuktikan kebangkitan Kristus. Selain itu, dalam teologi biblika, Wright juga dikenal karena menggunakan pendekatan narasi dalam melihat teologi biblika. ${ }^{17}$ Penulis memakai konsep Wright karena dua alasan.

15. Daniel Strange, "Not Ashamed!: The Sufficiency of Scripture for Public Theology," Themelios 36 no. 2 (2011): 241.

16. Lih. Daniel Strange, "Evangelical Public Theology: What on Earth? Why on Earth? How on Earth," dalam A Higher Throne: Evangelicals and Public Theology, ed. Chris Green (Nottingham: Apollos, 2008), 18-19.

17. Lih. Craig G. Bartholomew dan Mike W. Goheen, "Story and Biblical Theology," dalam Out of Egypt: Biblical Theology and Biblical Interpretation, ed. Craig Bartholomew, Mary Healy, Karl Moller, dan Robin Parry (Grand Rapids: Zondervan, 2004), 144-50. Wright melihat Alkitab sebagai sebuah cerita besar utuh (yang biasa dsebut metanarasi) yang dibagi ke dalam lima babak: (1) penciptaan, (2) kejatuhan, (3) Israel, (4) Yesus, dan (5) Umat PB (Christian Origins and the Question of God, vol. 1 dari The New 
Pertama, Wright sendiri memiliki kontribusi yang cukup besar di kalangan injili. ${ }^{18}$ Kedua, perspektif ciptaan baru Wright belum banyak dibahas dan diarahkan ke dalam perspektif Indonesia.

Dengan lensa hermeneutis ciptaan baru, Wright membangun teologi biblika yang dapat menjadi kerangka teologi publik. la memberikan kerangka ciptaan baru sebagai praksis hidup orang percaya yang berada dalam dunia tapi tidak serupa dengan dunia. Wright melihat bahwa bagi Paulus ciptaan baru justru menjadi teologi publik yang seharusnya dihidupi orang percaya. ${ }^{19}$ Wright menekankan bahwa metanarasi karya penebusan Allah yang

Testament and the People of God [Minneapolis: Fortress, 1992], 141-43). Pendekatan ini juga memengaruhi beberapa sarjana seperti Craig Bartholomew, Michael Goheen, dan Kevin J. Vanhoozer.

18. Kontribusi Wright bagi kaum injili terlihat dari beberapa sarjana injili yang mengakui perannya, seperti Michael F. Bird yang secara khusus membuat satu ekskursus di dalam monografnya tentang ortodoksi N.T. Wright (Michael F. Bird, The Saving Righteousness of God: Studies on Paul, Justification, and the New Perspective [Eugene: Wipf and Stock, 2007]) dan Thomas Schreiner yang melihat Wright sebagai kawan dari Evangelical Theological Society walau ia tidak setuju dengan teologi Paulus dari Wright (Thomas Schreiner, "Justification: The Saving Righteousness of God in Christ," JETS 54 no. 1 [Maret 2011]: 19).

19. "This opens up a new perspective (so to speak) on the question not only of the origin of Paul's ethics but of what we might call his 'public theology.' ... for Paul the whole point was that a new world had been launched in and through Jesus ... Paul believed, on classic Jewish grounds, that this new world was the new creation" (N.T. Wright, Christian Origins and the Question of God, vol. 4 dari Paul and the Faithfulness of God [Minneapolis: Fortress, 2013], 1100). Penekanan dari penulis. 
dinyatakan dalam praksis hidup orang percaya seharusnya bersifat publik, subversif, dan mengubahkan dunia. ${ }^{20}$

1. Cerita dunia: Gema-gema dari sebuah suara (echoes of a voice) Paulus pernah mengatakan kepada jemaat Roma bahwa seluruh ciptaan menantikan saat anak-anak Allah dinyatakan (Rom. 8:19). Perkataan Paulus yang tidak hanya merujuk kepada manusia tetapi kepada seluruh ciptaan ini merupakan suatu gambaran dunia yang diciptakan Allah dengan sungguh amat baik namun di saat yang bersamaan ada dalam perbudakan dosa. Wright melihat bahwa Paulus di ayat ini sedang menggemakan sebuah penantian yang berakar pada pengharapan Yahudi, yakni sebuah pengharapan kosmis akan kehidupan baru yang akan dimulai oleh Allah sendiri. ${ }^{21}$

Dalam konteks ini, ciptaan sama-sama mengeluh sakit bersalin sekaligus menantikan dengan penuh pengharapan (Rom. 8:22). Penantian ini sebetulnya kembali kepada gema dari Kejadian ketika Allah mencurahkan kasih-Nya untuk menciptakan dunia yang la katakan "sungguh amat baik." Allah menata dunia sedemikian rupa dari ketidakberaturan (chaos) menuju keteraturan sehingga menunjukkan kehadiran, kuasa, maupun kemuliaan-Nya atas seluruh

20. Lebih lanjut, Wright berkata: "Wise, holistic exegesis is a 'common good' project, and in turn it serves the larger common good projects that our world so badly needs" (Surprised by Scripture: Engaging Contemporary Issues [New York: HarperCollins, 2014], 181).

21. N.T. Wright, Surprised By Hope: Rethinking Heaven, Resurrection, and the Mission of the Church (New York: HarperCollins, 2008), 103. 
bumi. Namun, sejak dunia jatuh dalam dosa, dunia berada dalam "pembuangan," kembali ke dalam chaos dan menantikan saat di mana Allah menata kembali segala sesuatunya. ${ }^{22}$

Penantian protologis-eskatologis inilah yang dihayati di dalam diri setiap manusia dalam bentuk "gema-gema dari sebuah suara" (echoes of a voice). Manusia di berbagai tempat dan waktu memiliki setidaknya empat gema: keadilan, spiritualitas, relasi, dan estetika/keindahan. ${ }^{23}$ Semua kerinduan ini, bagi Wright, merupakan sebuah penunjuk (signpost), yang walaupun samar-samar, berasal dari satu suara yang sama yang terus-menerus memanggil seluruh ciptaan, termasuk manusia. Dengan kata lain, cerita dunia adalah cerita tentang gema yang ada di dalam diri manusia. Wright sendiri melihat gema ini muncul dalam setiap aspek manusia, seperti budaya, ekspresi agama, dan lain sebagainya. Gema-gema ini justru menantang seluruh manusia untuk mencari cerita macam apa yang mampu menjawab kerinduan dan menunjukkan siapa suara yang memanggil manusia ini. ${ }^{24} \mathrm{Di}$ sinilah kisah kekristenan, yakni kisah pengharapan tentang Allah yang dikenal dalam diri Yesus Kristus,

22. Wright, Christian Origins, 299.

23. N.T. Wright, Simply Christian: Why Christianity Makes Sense (New York: HarperCollins, 2006), ix. Dalam teologi publik, hal ini sebetulnya senada dengan konsep natural law (lih. Hainsworth, Deirdre King dan Paeth, Scott R., Public Theology for a Global Society: Essays in Honor of Max Stackhouse. Grand Rapids: Eerdmans, 2009 "Introduction," xi).

24. Hainsworth dan Paeth, "Introduction," xi. 
menjadi metanarasi yang mengklaim kebenaran dari suara dalam cerita dunia ini. ${ }^{25}$

2. Cerita Allah: Pencipta, Penebus, dan Raja dari sebuah revolusi

Orang-orang Yahudi pada masa Bait Allah Kedua (SecondTemple Judaism) memiliki pengharapan bahwa akan tiba saatnya YHWH-melalui Mesias-kembali bersama umat-Nya dan merestorasi Bait Allah, membawa mereka keluar dari perbudakan Roma, memulihkan hukum Taurat dan bertakhta sebagai raja atas semesta. ${ }^{26}$ Namun, bagi mereka, masa yang baru itu masih akan datang di titik akhir sebagai klimaks sejarah, bukan pada masa itu. ${ }^{27}$

Pengharapan inilah yang sebetulnya digenapkan secara progresif sekaligus klimaks dalam diri Kristus. Wright berkata, "It is basic to early Christianity that the Jewish hope has already been fulfilled. 'All the god-given promises find their "yes" in Christ,' said Paul."28 Lebih jauh lagi, orang Kristen mula-mula memandang penggenapan zaman akhir yang dimulai oleh Allah sendiri itu bukan lagi hanya pada masa yang akan datang, melainkan masa kini, melalui Kristus. Afirmasi dari pengharapan ini dilandaskan pada seluruh

25. Wright, Simply Christian, 46.

26. N.T. Wright, Christian Origins and the Question of God, vol. 2 dari Jesus and the Victory of God (Minneapolis: Fortress, 1996), 477-78. Wright sendiri membangun argumennya dari literatur-literatur orang Yahudi pada masa Bait Allah Kedua.

27. Wright, Christian Origins and the Question of God, 299, 301.

28. Wright, Christian Origins and the Question of God, 459. 
kehidupan dan karya Kristus sendiri, terutama kematian dan kebangkitan-Nya yang menjadi tanda kedatangan kerajaan Allah.

Menurut Wright, penyerahan diri Kristus melalui penyalibanNya bukan hanya menghasilkan pengampunan dosa manusia tetapi justru merupakan tanda oposisi sekaligus parodi kerajaan Allah terhadap kuasa Kaisar yang menggunakan pedang untuk menundukkan lawannya. "Kerajaan-Ku bukan dari dunia ini ...," kata Yesus (Yoh. 18:36). ${ }^{29}$ Jika sebelum Yesus ada orang-orang Yahudi yang mengklaim dirinya sebagai Mesias melalui pedang dan kekerasan, Yesus mengklaim bahwa jalan panggilan kerajaan Allah adalah jalan kasih, jalan penyerahan diri sebagai hamba Allah (bdk. Yes. 52:13-53:12). Justru melalui kasih di atas kayu saliblah Yesus memulai sebuah revolusi kasih. ${ }^{30}$ Menggenapi apa yang dikatakan oleh Kitab Suci, Yesus ditinggikan dan dimuliakan menjadi raja atas segala raja di atas kayu salib (bdk. Yoh. 3:14-16), sedangkan Kaisar, yang memerintah dengan tangan besi dan melambangkan kuasa

29. Wright memandang bahwa dalam kisah Yesus dan Pilatus di Injil Yohanes, Yesus adalah representasi kerajaan Allah, sedangkan Pilatus merepresentasikan kerajaan Kaisar. Yesus berdiri di hadapan Pilatus menunjukkan oposisi kerajaan Allah dengan kerajaan dunia. Kerajaan Allah ini bukan berasal dari dunia, tetapi untuk dunia. Di hadapan Pilatus, Yesus menantang Kaisar dengan berkata kepada Pilatus bahwa ia tidak punya kuasa (exousia) apapun terhadap Yesus kalau itu tidak diberikan dari atas (lih. N.T. Wright, God in Public: How the Bible Speaks Truth to Power Today [London: SPCK, 2016], 51-55; bdk. N.T. Wright, How God Became King: The Forgotten Story of the Gospels [New York: HarperCollins, 2012], 134-35).

30. Wright, Jesus and the Victory of God, 595. 
dunia, direndahkan. ${ }^{31}$ Di salib jugalah Kristus sebagai "raja orang Yahudi" menggenapkan dan memulihkan vokasi Israel melalui pengampunan dosa, untuk menjadi terang bagi bangsa-bangsa di dunia yang belum mengenal Allah, menyatakan kembali kehadiran dan kemuliaan-Nya di dunia. Yesus menunjukkan apa artinya menjadi Israel sejati yang Allah panggil untuk memiliki hati yang diperbarui dan menggenapkan rencana Allah bagi dunia. ${ }^{32}$

Karya Kristus berlanjut di dalam kebangkitan-Nya. Kebangkitan Kristus, sama seperti pengharapan restorasi Israel, merupakan sebuah indikasi bagi status-Nya sebagai Mesias (bdk. Yeh. 37). Kebangkitan badani merupakan pengharapan orang Yahudi ketika tiba saatnya nanti Tuhan akan membenarkan dan memulihkan umat-Nya. ${ }^{33}$ Kristus sebagai "Israel baru" merestorasi dunia dengan menjadi yang pertama bangkit dan menghadirkan pengharapan itu pada masa kini. Dalam kebangkitan tubuh-Nya, Kristus telah menjadi Bait Allah yang menghadirkan kerajaan, kuasa, dan kemuliaan Allah (Yoh. 2:19). Artinya, melalui kebangkitan Kristus, penggenapan ciptaan baru sudah digenapi walaupun belum sepenuhnya (already

31. N.T. Wright, "Paul's Gospels and Caesar's Empire," dalam Paul and Politics: Ekklesia, Israel, Imperium, Interpretation, ed. Richard A. Horsley (Harrisburg: Trinity, 2000), 183.

32. N.T. Wright, The Day the Revolution Began: Rethinking the Meaning of Jesus' Crucifixion (London: SPCK, 2016), 81.

33. Wright, Surprised by Hope, 56. 
but not yet). Ciptaan baru telah datang dalam diri Kristus ketika la bangkit dari antara orang mati. ${ }^{34}$

3. Allah di ruang publik: Vokasi ciptaan baru

Bagi Wright, narasi Kristen adalah kisah Allah di ruang publik. ${ }^{35}$ la melihat bahwa Allah memanggil orang percaya bukan hanya supaya jiwa kita pergi dari dunia, meninggalkan tubuh yang fana dan menuju surga yang mulia. ${ }^{36}$ Sebaliknya, Allah telah menubuhkan surga itu di bumi melalui rekonsiliasi dalam Kristus. Surga itu dinyatakan di tengah dunia sesuai dengan visi Allah saat Yerusalem yang baru akan turun dan memulihkan dunia (Why. 21). ${ }^{37}$ "Jadi," kata Paulus, "siapa yang ada di dalam Kristus, ia adalah ciptaan baru: yang lama sudah berlalu, sesungguhnya yang baru sudah datang" (2Kor. 5:17). Narasi keselamatan yang dinyatakan melalui kematian dan kebangkitan Kristus mengklaim bahwa Kristuslah suara yang memanggil sekaligus memulihkan dunia itu.

Cerita Allah yang bekerja di dalam cerita dunia inilah yang dihidupi oleh orang-orang Kristen mula-mula. Orang-orang Kristen abad pertama memiliki praksis yang jelas-jelas berbeda dari hegemoni praksis paganisme sebagai mayoritas pada saat itu. Praksis hidup mereka merupakan antisipasi/cicipan (foretaste) dari

34. Wright, Surprised by Hope, 67. Bdk. N.T. Wright, Christian Origins and the Question of God, vol. 3 dari The Resurrection of the Son of God (Minneapolis: Fortress, 2003), 578.

35. Wright, Surprised by Scripture, 173.

36. Wright, New Testament and the People of God, 253-54.

37. Wright, Surprised by Hope, 104. 
pemerintahan Allah itu. Orang-orang pagan pada saat itu melihat praksis hidup yang radikal dari orang-orang yang disebut pengikut Kristus: mereka tidak terlibat dalam imoralitas seksual, tidak mempersembahkan korban kepada dewa, tidak memberontak paksa terhadap pemerintah, dan menunjukkan kasih yang radikal terhadap sesama. ${ }^{38}$ la berkata, "The main thing that would have struck observers of early Christianity was not its 'religious' side, nor indeed its early doctrinal formulations, but its total way of life." ${ }^{39}$ Gaya hidup di tengah-tengah pandangan dunia pagan inilah yang kemudian menjadi sebuah proklamasi Injil bahwa Yesus adalah Tuhan atas dunia yang menjawab gema dalam diri setiap manusia.

Praksis yang menyatakan cerita Allah di ruang publik ini didasarkan setidaknya atas dua vokasi, yakni imam (priests) dan penguasa (rulers). Ketika Allah menciptakan manusia sesuai dengan gambar dan rupa-Nya, Allah ingin agar kuasa, kehadiran dan kemuliaan-Nya dinyatakan atas seluruh ciptaan melalui manusia (Kej. 1:26-28). Manusia menyandang status sebagai wakil Allah dalam mengerjakan proyek ilahi-Nya bagi ciptaan, yakni menyatakan kemuliaan dan keagungan-Nya di seluruh bumi. ${ }^{40}$ Proyek ilahi ini dilanjutkan dengan memilih bangsa Israel sebagai "imamat rajani/kerajaan imam" (Kel. 19:4-6; 1Pet. 2:9). Dalam ciptaan baru, orang-orang percaya dipanggil untuk menunjukkan kuasa

38. Wright, New Testament and the People of God, 362-63.

39. Wright, New Testament and the People of God, 120.

40. N.T. Wright, After You Believe: Why Christian Character Matters (New York: HarperCollins, 2010), 89. 
pemerintahan Allah (rulers) sekaligus menjadi imam yang memediasi dunia kepada Allah (priests) melalui Roh Kudus yang memulai karya itu dalam diri manusia. ${ }^{41}$ Dengan kata lain, setiap praksis orang percaya dalam memperjuangkan keadilan, mengejar kedamaian, menghapus kemiskinan, merupakan sebuah antisipasi kerajaan Allah yang dinyatakan di ruang publik. ${ }^{42}$

\section{Allah di Ruang Publik Indonesia: Misi Ciptaan Baru sebagai Praksis Kaum Injili di tengah Bangsa Indonesia}

Dari pemaparan di atas, teologi ciptaan baru Wright berfokus pada teologi biblika sekaligus berusaha memberikan sebuah paradigma teologis untuk menjawab isu-isu publik. Apa peran seorang Kristen di bumi Pancasila yang majemuk sekaligus diwarnai konflik ini? Tidak lain adalah seorang Kristen dapat memainkan drama ciptaan baru di ruang publik. Peran orang Kristen di ruang publik selalu bersumber dari misi Allah (missio Dei) atas ciptaan. Ciptaan baru berbicara tentang kehadiran dan karya Allah yang bukan hanya di ruang privat, tetapi juga ruang publik (God in public). ${ }^{43}$ Narasi kematian dan kebangkitan Yesus merupakan sebuah proklamasi di ruang publik bahwa Yesus adalah Raja yang hadir di tengah-tengah dunia.

41. Wright, After You Believe, 80-81.

42. Wright, After You Believe, 66.

43. Wright, Surprised by Scripture, 167. 
Dalam konteks Indonesia, Pancasila sebagai agama sipil memungkinkan setiap agama untuk tetap memainkan peranan publiknya tanpa disekularisasi ataupun didominasi oleh kelompok mana pun. Penulis melihat justru ruang publik yang bebas namun tetap dalam koridor agama sipil Pancasila inilah yang memberikan ruang bagi praksis ciptaan baru untuk dinyatakan. Hal ini seharusnya mendorong setiap orang percaya untuk terlibat di dalam ruang publik dan mewartakan Injil Kristus. Vokasi ciptaan baru justru memampukan setiap orang percaya untuk menjadi imam dan penguasa atas dunia milik Allah. Ini berarti di mana orang percaya berada, di situ kerajaan Allah sudah dan sedang hadir. Natur publik dari proklamasi keselamatan ini menuntut sebuah aksi nyata dari orang percaya untuk membawa kisah Allah dari ruang privat tiap-tiap komunitas Kristen menuju ruang publik.

1. Praksis ciptaan baru dalam multikulturalisme di Indonesia

a) Perjumpaan antar narasi agama-agama

Bertolak dari konsep pandangan dunia Wright, setiap kebudayaan ataupun agama memiliki titik pijak narasi masingmasing. ${ }^{44}$ Dengan kata lain, ruang publik Indonesia yang multikultural terdiri dari narasi agama-agama. Setiap agama menceritakan sebuah

44. Wright, Christian Origins and the Question of God, 69-71. Cerita merupakan aspek yang fundamental dalam pandangan dunia karena kehidupan manusia dibentuk oleh cerita-cerita yang membingkai (controlling story) setiap pengalaman-pengalaman manusia dalam realitas. Setiap tindak-tanduk manusia selalu menceritakan cerita di mana mereka berada. 
kisah tertentu yang dihidupi melalui praksis kehidupan pemelukpemeluknya. Kehidupan praksis seorang Kristen di Indonesia mau tidak mau akan selalu berada di antara narasi lain, sehingga praksis hidup dari narasi apapun selalu membuatnya terlibat dalam ruang publik.

Ditambah lagi, Pancasila sebagai ideologi negara seharusnya memungkinkan narasi itu bisa saling berkontribusi dan bertemu dengan bebas di ruang publik tanpa kekangan apapun. Tidak hanya itu, setiap narasi juga dimungkinkan untuk berkontribusi dalam kehidupan berbangsa dan bernegara tanpa ada tekanan. Dengan demikian, mau tidak mau di dalam ruang publik Indonesia pasti terjadi perjumpaan antar narasi yang menimbulkan tabrakan pandangan dunia (clash of worldviews). Harold Netland menyebut perjumpaan antar agama ini sebagai "klaim kebenaran yang bertentangan" (conflicting truth claims). ${ }^{45}$ Walaupun memang ada agama-agama yang beririsan (contohnya Kristen dan Islam), ada klaim-klaim fundamental yang tidak bisa dikompromikan, seperti misalnya masalah keselamatan di dalam Kristus. ${ }^{46}$ Ruang publik

45. Harold Netland, Encountering Religious Pluralism: Tantangan bagi Iman \& Misi Kristen, terj. Selviya Hanna (Malang: Literatur SAAT, 2015), 196.

46. Netland, Encountering Religious Pluralism, 197. Netland memandang setidaknya ada tiga pertanyaan dasar yang ada pada setiap narasi agama, yakni (1) pertanyaan mengenai natur religius ultimat; (2) pertanyaan mengenai natur manusia; dan (3) pertanyaan mengenai natur keselamatan. 
menjadi sebuah tempat di mana setiap narasi agama menceritakan kisah yang hendak menjawab gema-gema dari sebuah suara itu. ${ }^{47}$

Dengan kata lain, perjumpaan narasi antar agama ini bukan mengaburkan identitas eksklusif milik masing-masing agama karena narasi selalu bersifat normatif. ${ }^{48}$ Sebaliknya, narasi-narasi eksklusif inilah yang sebetulnya dipertontonkan melalui apa yang dihidupi oleh tiap pemeluk agama dalam ruang publik. Setiap orang dalam ruang publik adalah story-teller dari narasi mereka masing-masing. Meminjam istilah Alasdair Maclntyre, Wright berkata bahwa setiap praksis manusia adalah "narasi yang diperankan" (enacted narratives). ${ }^{49}$

Perjumpaan antar narasi dalam konteks yang multikultural ini sebetulnya sangat mirip dengan konteks gereja mula-mula. Sebagai minoritas di tengah agama-agama pagan, praksis kekristenan mula-mula justru menunjukkan sebuah pandangan dunia yang sangat berbeda dari kaum pagan. Dengan kehadiran kekristenan mula-mula, Allah yang mereka sembah dalam Kristus seakan-akan menantang allah-allah kaum pagan. ${ }^{50}$ Mereka tidak hanya mempertahankan identitas eksklusif mereka sebagai pengikut Kristus, tetapi juga membawa identitas itu di hadapan ruang publik untuk menawarkan pandangan dunia Kristen sebagai metanarasi yang lebih superior dari pandangan dunia lainnya. Tidak heran bila

47. Wright, Evil and the Justice of God (London: SPCK, 2006), 15-16.

48. Wright, Christian Origins and the Question of God, 41.

49. Wright, Christian Origins and the Question of God, 38.

50. Wright, Christian Origins and the Question of God, 362-64. 
komunitas yang disebut pengikut Yesus dari Nazaret ini masih terus eksis walaupun pendirinya dianggap telah mati.

Jika demikian, bagaimana seorang Kristen injili merefleksikan identitasnya di tengah narasi agama-agama dalam konteks multikulturalisme di Indonesia? Seorang Kristen harus melihat bahwa dirinya selalu terlibat dalam ruang publik di tengah narasi agamaagama lain. Tidak mungkin orang percaya dapat hanya melihat dirinya sendiri tanpa melihat kepelbagaian sebagai sebuah realitas. ${ }^{51}$

Orang percaya di Indonesia seharusnya melihat vokasi dirinya sebagai pembawa metanarasi Allah, yakni kisah yang membawa berita tentang Kristus yang menyelamatkan dan memulihkan seluruh ciptaan. Orang-orang Kristen sedang hidup di dalam babak kelima (fifth act), dan setiap tindak-tanduk, pikiran, perkataan, maupun perbuatan mereka pasti akan terus menggemakan identitasnya sebagai pembawa narasi Allah. ${ }^{52}$ Kehadiran seorang Kristen di ruang publik sebetulnya sedang mempertontonkan Injil sebagai kebenaran publik (public truth), yakni pandangan dunia yang mampu menjawab gema-gema seluruh

51. Bdk. Miroslav Volf, Exclusion \& Embrace: Theological Exploration of Identity, Otherness, and Reconcilliation (Nashville: Abingdon, 1996), 17-18.

52. Kevin J. Vanhoozer juga mengembangkan konsep praksis hidup seorang Kristen dengan pendekatan teatrikal atau dramaturgi. Baginya, vokasi setiap orang percaya adalah untuk menjadi aktor yang autentik di dalam teodrama Allah. Alkitab menjadi naskah (script) yang harus diperankan oleh setiap orang percaya (lih. Kevin J. Vanhoozer, Drama Doktrin: Suatu Pendekatan Kanonik-Linguistik pada Theologi Kristen, terj. Satya Limanta [Surabaya: Momentum, 2007], 489, 492-94). 
dunia. ${ }^{53}$ Jika demikian, kisah kekristenan di ruang publik sedang menantang pandangan dunia lain. ${ }^{54}$ Ketika disandingkan dengan narasi agama lain, maka seharusnya narasi Kristenlah yang mengklaim dan menunjukkan diri sebagai metanarasi ruang publik yang mampu menjawab gema dalam diri manusia maupun ciptaan. ${ }^{55}$

b) Dari Ghetto menuju dialog

Jika perjumpaan antar narasi dalam konteks multikultural di Indonesia ini tak terhindarkan, dialog menjadi sebuah keharusan. Pengakuan iman yang eksklusif terhadap ketuhanan Kristus seharusnya tidak membuat gereja anti terhadap dialog dengan agama lain. Sebaliknya, justru proklamasi publik kerajaan Allahlah yang membuat daya Injil bergerak dari dalam ke luar (sentrifugal) dan "menemui" pandangan dunia lain. Seringkali, konflik antar agama di Indonesia semakin meradang tidak selalu karena perbedaan fundamental agama-agama (misalnya antara Kristen dan Islam),

53. Wright, Christian Origins and the Question of God, 42; bdk. Wright, God in Public, 10.

54. Brian J. Walsh, Subversive Christianity: Imaging God in A Dangerous Time, ed. ke-2 (Eugene: Wipf and Stock, 2014), 18-24. Walsh menggambarkan kehidupan Kristen di dunia ini dalam gambaran orang Israel yang ada dalam pembuangan di Babel. Umat Allah pada masa pembuangan itu dipenuhi oleh gambaran-gambaran imajinatif Babel untuk memengaruhi pandangan dunia mereka. Di tengah imajinasi pandangan dunia Babel inilah Tuhan memanggil dan memulihkan bangsa Israel untuk membalikkan pandangan dunia itu dengan cerita tentang Allah. Itulah sebabnya orang percaya juga dipanggil untuk menjadi gambar dan rupa Allah, membalikkan nilai-nilai dunia dengan pandangan dunia Kristen.

55. Wright, Christian Origins and the Question of, 41-42. 
tetapi karena tidak adanya dialog. Dialog pun sering disalahmengerti sebagai upaya untuk mencari Tuhan yang sama. Tidak heran bila dialog sering ditakuti, diabaikan, dan tidak diprioritaskan. ${ }^{56}$

Dalam praksis ciptaan baru, dialog merupakan wadah perjumpaan antar narasi di ruang publik yang memungkinkan terjadinya perubahan pandangan dunia. Dialog memungkinkan narasi yang bertemu untuk saling ditantang dan diubahkan. ${ }^{57}$ Tanpa dialog, perjumpaan yang terjadi tidak akan menumbuhkan komunikasi maupun relasi. Memang dialog sendiri pada akhirnya harus berujung pada pekabaran Injil. ${ }^{58}$ Dialog sendiri adalah sebuah proklamasi sekaligus kesaksian. Namun, di tengah konflik dan kekerasan antar agama di Indonesia, dialog sebetulnya membuka jalan bagi penerimaan dan kasih dengan menghapus sekat-sekat yang merintangi relasi antar agama. ${ }^{59}$ Volf sendiri mengatakan justru

56. Bdk. Adrianus Yosia, "Mendramakan Doktrin sebagai Bentuk Partisipasi Kaum Injili pada Dialog Antar-Iman di Indonesia" (Skripsi M.Div, STT SAAT, 2017), 20-21.

57. Gerald R. McDermott dan Harold A. Netland, A Trinitarian Theology of Religions: An Evangelical Proposal (New York: Oxford University, 2014), 280-81.

58. John Stott, seorang tokoh yang berpengaruh di kalangan injili, mengatakan bahwa dalam menyikapi pluralisme agama orang-orang Kristen tidak dapat jatuh ke dalam dua ekstrem, yakni pemaksaan di satu segi dan toleransi berlebihan yang tidak menghasilkan apa-apa di sisi lainnya. Sebaliknya, seorang Kristen harus melakukan persuasi dengan kasih untuk menunjukkan nilai-nilai Kristen yang sesungguhnya (John Stott, New Issues Facing Christians Today, edisi revisi [London: Marshall Pickering, 1990], 5562).

59. Bdk. Armand Riyanto, Dialog Interreligius: Historisitas, Tesis, Pergumulan, Wajah (Yogyakarta: Kanisius, 2010), 404-6. 
dialog di ruang publik memungkinkan agama-agama untuk berbagi hikmat (sharing wisdom). ${ }^{60}$ Jika gereja mengakui bahwa jalan mengikut Kristus adalah jalan hikmat seorang manusia sejati, maka justru gereja tidak sepatutnya mengabaikan momen untuk membagikan Kristus, Sang Hikmat llahi.

Memang, dialog di sini tidak dapat dipandang dalam arti sempit. Netland membagi dialog ke dalam dua bentuk, yakni formal dan informal. ${ }^{61}$ Dialog formal biasa diprakarsai oleh lembagalembaga ataupun organisasi-organisasi untuk membangun jembatan antar umat beragama. Dialog yang kedua, yakni dialog informal, didefinisikan sebagai pertemuan antara dua pihak dari agama yang berbeda. Dialog pun tidak selalu berbentuk verbal, tetapi juga karya. ${ }^{62}$ Misalnya, ketika sebuah komunitas multikultural (agama Kristen dengan agama-agama lain) mencoba menyelesaikan masalah kemiskinan di daerah mereka, setiap narasi agama-agama pasti memiliki pandangannya masing-masing. Entah pada akhirnya terjadi konsensus bersama atau tidak, dalam dialog karya ini komunitas multikultural sedang saling bertukar hikmat dan kesaksian Kristen akan Allah yang mengklaim ruang publik juga sedang dinyatakan. ${ }^{63}$

60. Miroslav Volf, Public Faith: How Followers of Christ should Serve the Common Good (Grand Rapids: Brazos, 2011), 103-4.

61. Harold Netland, Dissonant Voices: Religious Pluralism and the Question of Truth (Grand Rapids: Eerdmans, 1991), 296-97.

62. Riyanto, Dialog Interreligius, 213.

63. John G. Stackhouse, Jr., Making the Best of It: Following Christ in the Real World (Oxford: Oxford University, 2011), 326. 
Di kalangan injili, dialog sebetulnya bukan hal yang asing. Harus diakui, dialog yang selama ini dilakukan kaum injili di Indonesia masih terkesan apologetis dan ofensif. ${ }^{64}$ Walaupun demikian, kalangan injili sedunia sendiri sudah mengakui kecenderungan ini dan memang juga sudah sejak lama mengakui bahwa dialog sangat diperlukan untuk membangun jembatan relasi dengan agama-agama lain. Manila Manifesto menyatakannya dengan sangat jelas dengan mengatakan: ${ }^{65}$

In the past we have sometimes been guilty of adopting towards adherents of other faiths attitudes of ignorance, arrogance, disrespect and even hostility. We repent of this. We nevertheless are determined to bear a positive and uncompromising witness to the uniqueness of our Lord, in his life, death and resurrection, in all aspects of our evangelistic work including inter-faith dialogue.

64. Hal ini bukan berarti penulis menolak bahwa tidak perlu ada penyingkapan kebenaran dalam dialog. Pertanyaan dan jawaban tentang kebenaran tetap merupakan hal yang fundamental. Namun, yang penulis maksudkan di sini adalah dialog yang selama ini dilakukan cenderung untuk menghakimi dan menunjukkan secara langsung bahwa agama lain salah dan perlu bertobat ketimbang menunjukkan itikad baik untuk mengenal, merangkul, dan membawa mereka kepada Kristus. Aritonang dan Steenbrink sendiri mengatakan, "Dealing with the relationship with the people of other faiths, especially Muslims, as already mentioned, the Evangelicals-Pentecostals are also aware of the importance of dialogue with people of other faiths. But many of these dialogues show an atmosphere of apologetic and polemic on doctrine rather than seeking for mutual understanding and respect" (Jan Aritonang dan Karen Steenbrink, A History of Christianity in Indonesia [Leiden: Brill, 2008], 898-99).

65. Second Lausanne International Congress on World Evangelization, "The Manila Manifesto (Excerpt)," International Bulletin of Missionary Research 13 no. 4 (Oktober 1989): 166. 
Karena itu, penginjilan tidak lagi dapat dipandang dalam arti yang sempit hanya sebatas menantang atau mengundang orang untuk percaya kepada Kristus. Penginjilan adalah sebuah proklamasi yang dinyatakan melalui kesaksian hidup. Walaupun tantangan itu pada akhirnya tetap dibutuhkan, dialog merupakan bagian yang sentral karena membangun relasi bagi orang yang belum percaya agar dapat melihat kesaksian hidup orang percaya.

\section{c) Radikalisme agama}

Sepanjang sejarah, ruang publik Indonesia dinodai oleh sikap radikalisme agama yang selama ini banyak juga melibatkan orang percaya di dalamnya. Ketegangan dan konflik ini memang pada umumnya selalu berkaitan erat dengan relasi Muslim dan Kristen. Walaupun Indonesia terkenal sebagai bangsa yang toleran, masih banyak kasus-kasus di lapangan yang menunjukkan bahwa radikalisme agama masih menjadi sorotan di Indonesia. Hal ini pun diperkuat oleh aksi-aksi teror yang terus terjadi, sehingga kekerasan antar agama tidak terhindarkan.

Jika kekristenan menggambarkan Kristus sebagai pemulih kosmis dari relasi sesama ciptaan yang sudah rusak, maka orangorang Kristen sebagai imamat rajani (royal priesthood) seharusnya menjadi mediator pemulihan relasi dengan sesama. Praksis ciptaan baru tidak dinyatakan dengan membalas kekerasan ataupun radikalisme dengan "anarkisme suci" (holy anarchy) yang 
mengatasnamakan Allah demi melegitimasi kekerasan. ${ }^{66}$ Sebaliknya, panggilan seorang Kristen adalah untuk mengasihi musuh (Mat. 5:44) sebagai bagian dari mengasihi Allah dan mengasihi sesama seperti diri sendiri (Luk. 10:27).

Jika demikian, bagian dari orang percaya di Indonesia untuk bersikap dalam konteks radikalisme agama ini adalah meneladani Kristus sendiri dengan memikul salib sebagai gaya hidup (cruciform). ${ }^{67}$ Ketika Kristus didesak dari semua pihak yang membenci-Nya, la membalasnya dengan kasih dan pengampunan di atas kayu salib. Teladan Kristus ini dihidupi sepanjang sejarah kehidupan orang percaya dengan menempuh jalan salib untuk menjadi martir. ${ }^{68} \mathrm{Jika}$ di atas salib ada pengampunan dan rekonsiliasi, maka orang Kristen di Indonesia yang banyak mengalami luka di masa lalu harus pertama-tama mempraktikkan kasih dan pengampunan yang mengubahkan hidup. ${ }^{69} \mathrm{Di}$ salib, tidak ada lagi kebingungan

66. Wright, God in Public, 65. Bdk. Wright, Surprised by Scripture, 175. Dalam hal ini, praksis Wright sebetulnya lebih condong kepada pasifisme atau nonkekerasan.

67. Wright, The Day the Revolution Began, 406-7.

68. Kevin J. Vanhoozer, Pictures at Theological Exhibition: Scenes of Church's Worship, Witness, and Wisdom (Downers Grove: InterVarsity, 2016), 242. Di sini Vanhoozer menjelaskan pendekatan "sapiential apologetics" yang menekankan kesaksian lewat menghidupi drama Kristus ketimbang argumen-argumen proposisional. Baginya, apologetika tanpa drama kemartiran adalah apologetika murahan.

69. Wright, The Day the Revolution Began, 385. Volf mengatakan, "A combination of moral clarity that does not shy away from calling evil by its proper name and of deep compassion toward evildoers that is willing to sacrifice one's own life on their behalf was one of the extraordinary features 
antara kasih dan keadilan. Volf menyebut panggilan untuk meneladani salib Kristus ini sebagai "drama of embrace." la berkata: ${ }^{70}$

... the only available options are either to reject the cross and with it the core of the Christian faith or to take up one's cross, follow the Crucified-and be scandalized ever anew by the challenge. As the Gospel of Mark reports, the first disciples followed and were scandalized (14:26ff). Yet they continued to tell the story of the cross ... In his empty tomb they saw the proof that the cry of desperation will turn into a song of joy and that the face of God will eventually 'shine' upon a redeemed world.

2. Praksis ciptaan baru dalam perpolitikan Indonesia Oliver O'Donovan berkata: "Theology must be political if it is to be evangelical. Rule out the political questions and you cut short the proclamation of God's saving power; you leave people enslaved where they ought to be set free from $\sin$ - their own sin and others. ${ }^{\prime 71}$

Allah adalah Allah yang menyelamatkan. Karya-Nya itu tidak pernah berhenti pada aspek individual semata, tetapi juga struktur

of early Christianity. It should also be the central characteristic of contemporary Christianity (Volf, Public Faith, 132).

70. Volf, Exclusion and Embrace, 26-27. Justru ketika gereja berani merangkul orang-orang dari agama lain di tengah eksklusivitasnya [who is exclusive here? the church or people from other religions], gereja menjadi kesaksian [saksi(?)] yang menjawab gema relasi yang ada dalam diri manusia.

71. Oliver O'Donovan, The Desire of the Nations: Rediscovering the Roots of Political Theology (Cambridge: Cambridge University, 1996), 3. Walaupun O'Donovan berbicara dalam konteks Barat, penulis melihat hal yang sama juga berlaku di Indonesia, di mana peran agama diakui di dalam Pancasila. 
sosial seperti gereja, negara, bangsa, dan politik. Ketegangan selalu terjadi di antara dua kubu: sekularisme dengan pemisahan total gereja dan negara, serta fundamentalisme dengan dominasi dari agama terhadap negara.

Walaupun pada masa pembentukannya ada ketegangan dengan kaum fundamentalis Islam pada Piagam Jakarta, Pancasila yang menjadi produk akhir justru menjadi jalan tengah yang baik dengan tidak jatuh di antara keduanya. Sebetulnya ideologi Pancasila ini berjalan cukup harmonis dengan praksis ciptaan baru. Wright berkata, $^{72}$

Indeed, I want to suggest here that the Bible enables us to navigate a path of wisdom not just halfway between secularism and fundamentalism but on a trajectory that shows up those ugly brothers as simply missing the point, representing two opposing wings of a now thoroughly discredited worldview.

Di sinilah kisah kekristenan justru menawarkan sebuah jalan, bukan dengan sekularisme atau fundamentalisme, tetapi dengan menghidupi pengharapan yang ada di dalam Kristus, Sang Raja atas dunia.

Sama seperti Kristus melalui kehidupan dan karya-Nya menghadirkan sekaligus menyatukan surga dengan dunia, orang percaya di tengah bangsa Indonesia juga harus memandang diri-Nya ada di dalam dimensi yang sama. Kerajaan Allah bukanlah kerajaan

72. Wright, Surprised by Scripture, 165. 
yang ingin mencabut warganya untuk pergi dari dunia. Sebaliknya, realitas kerajaan Allah yang menjadi visi Kristus adalah kerajaan yang tidak berasal dari dunia namun untuk dunia. ${ }^{73}$ Dunia bukan lagi tempat yang fana, tetapi tempat di mana kerajaan Allah sudah dan akan dinyatakan. Karena itu, praksis yang dihidupi oleh orang percaya di Indonesia seharusnya menunjukkan ketaatan penuh kepada Kristus sebagai penguasa "di bumi seperti di surga."

Allah adalah Allah atas keteraturan (God of order) yang meniadakan kekacauan (chaos). Tujuan Allah semula menciptakan manusia seturut dengan gambar dan rupa-Nya adalah supaya manusia bisa mewujudkan tatanan dunia yang merefleksikan tatanan pemerintahan Allah di dunia. ${ }^{74}$ Karena kuasa/otoritas telah diberikan kepada Kristus di bumi seperti di surga, maka, penguasa-penguasa seburuk apapun ada di bawah otoritas ilahi untuk menyatakan tatanan pemerintahan-Nya bagi dunia. ${ }^{75}$ Orang percaya dipanggil untuk bersikap kritis dan menyuarakan kebenaran jika pemerintahan tidak berjalan dengan adil sesuai dengan visi Allah.

Akan tetapi, panggilan ini tidak serta merta membuat orang percaya selalu menjadi oposisi dari pemerintah yang sedang berkuasa. Di satu sisi, dengan taat kepada pemerintah Indonesia, orang percaya juga taat kepada otoritas Allah sekaligus berkontribusi bagi kerajaan-Nya agar dinyatakan di tengah bumi. Orang-orang

73. Wright, Surprised by Scripture, 169.

74. Wright, God in Public, 70.

75. Wright, Surprised by Scripture, 175. 
Kristen seharusnya mendukung pemerintah dalam mengejar kesejahteraan, kedamaian, dan aspek-aspek lainnya dari kehidupan bersama rakyat Indonesia. Semua itu justru menjadi alat di tangan Tuhan untuk menyatakan bahwa ciptaan ini sungguh amat baik. Namun, di sisi yang lain, di tengah realitas maraknya korupsi, penyelewengan kekuasaan, dan juga politik identitas, salah satu panggilan orang Kristen di Indonesia adalah menyuarakan kebenaran terhadap penguasa (speak truth to power). ${ }^{76}$

Panggilan ini dapat dikerjakan gereja bukan dengan berpuas diri dalam ruang privat sehingga memisahkan iman dari ruang publik. Panggilan ini juga bukan dikerjakan gereja dengan mencoba melakukan dominasi agresif terhadap pemerintahan dengan memasukkan orang-orang Kristen sebanyak-banyaknya dalam pemerintahan sehingga menciptakan pemerintahan yang dianggap "kristiani" sehingga agama lain kalah secara jumlah. ${ }^{77}$ Dalam ciptaan baru, justru gereja dapat mengerjakan panggilan ini dengan

76. Wright, Surprised by Scripture, 178.

77. Mengenai hal ini, Melba Padilla Maggay berkata, "Ide bahwa 'lebih banyak orang Kristen akan menghasilkan masyarakat yang lebih baik' mengabaikan fakta bahwa orang-orang percaya bisa punya kekhilafannya sendiri, seperti orang-orang Kristen dari tradisi Reformasi Belanda yang menjadi kelas penguasa lama di Afrika Selatan sebelum kepresidenan Nelson Mandela. Perumpamaan tentang lalang di antara gandum mengingatkan kita bagaimana kejahatan berjalin dengan kebaikan" (Melba Padilla Maggay, Transformasi Masyarakat: Refleksi Keterlibatan Sosial Kristen, terj. Yohannes Somawiharja [Jakarta: Cultivate, 2004], 55). Di sini, penulis tidak menganggap bahwa orang Kristen dengan demikian tidak perlu sama sekali masuk ke dalam pemerintahan. Penulis melihat bahwa panggilan itu harus dikerjakan dari berbagai sisi, tidak hanya oleh orangorang Kristen yang berada dalam pemerintahan. 
menunjukkan apa arti sebetulnya hidup di bawah ketuhanan (lordship) Kristus. ${ }^{78}$ Dalam bahasa James K. A. Smith, panggilan ini berarti gereja seharusnya dapat menjadi etalase kesaksian dari bagaimana seharusnya sebuah kota (polis) dijalankan. ${ }^{79}$ Sama seperti komunitas Kristen abad pertama, cara hidup komunitas Kristen di Indonesia ini justru memberikan kesaksian bahwa hidup gereja adalah antisipasi dari kerajaan Kristus. Ketika pemerintah dan penguasa justru tidak menjalankan tugas mereka sebagaimana mestinya, di situlah gereja menyuarakan kebenaran dan menantang penguasa dengan "cruciform theocracy"-gereja yang saling mengasihi, berkorban, mengampuni, serta mengejar kebaikan bersama ${ }^{80}$ Kekudusan hidup dari tiap-tiap orang percaya justru menunjukkan sekaligus menawarkan jalan untuk tinggal di dalam

78. Maggay, Transformasi Masyarakat: Refleksi Keterlibatan Sosial Kristen, 170.

79. James K.A. Smith, Awaiting the King: Reforming Public Theology, Cultural Liturgies 3 (Grand Rapids: Baker, 2017), 148-49. Sebetulnya konsep Wright tentang hubungan antara gereja dan negara cukup mirip dengan para teolog dari tradisi neo-Calvinisme seperti James K.A. Smith. Pandangan dari tradisi Kuyper ini berangkat dari ranah kedaulatan (sphere of sovereignty) di mana gereja dan negara memiliki daerah kedaulatannya masing-masing namun tetap saling beririsan dan memengaruhi (lih. James K.A. Smith, "The Reformed (Transformationist) View," dalam Five Views on Church and Politics, Counterpoints: Biblical Theology, ed. Amy E. Black [Grand Rapids: Zondervan, 2015], 150-58).

80. Wright, Surprised by Scripture, 178 dan Wright, God in Public, 173. Alan Storkey juga menyebut Yesus dalam kaitan politis dengan sebutan "the gentle ruler." Artinya, nilai-nilai kerajaan Allah yang dibawa oleh Kristus sangat bertolak belakang dengan pandangan dunia yang menekankan tirani dan kekuasaan untuk mencapai maksudnya (Alan Storkey, Jesus and Politics: Confronting the Powers [Grand Rapids: Baker, 2005], 282). 
dunia baru milik Allah. ${ }^{81}$ Gereja di Indonesia seharusnya memberikan kesaksian bahwa di tengah kekacauan bangsa dan dosa yang mengakar secara struktural, Kristus melalui diri-Nya memulihkan manusia dari dosa pribadi yang juga berimbas pada aspek struktural.

3. Praksis ciptaan baru dalam dimensi sosial

Jika kehadiran Allah dinyatakan sedemikian rupa melalui praksis Kristus yang mengidentifikasi diri dengan orang-orang terpinggirkan, maka orang percaya yang ada di "dalam Kristus" pun dipanggil untuk meneladani Kristus dan melakukan hal yang serupa untuk menghadirkan kerajaan Allah di bumi. Dalam praksis ciptaan baru, orang percaya dipanggil untuk mengejar kebaikan bersama (common good); artinya, praksis ciptaan baru bukan hanya menyentuh kehidupan individual, namun juga kebutuhan komunitas. Panggilan kebaikan bersama ini sesungguhnya didasari oleh vokasi ciptaan baru yang mengajak manusia kembali untuk menghayati bahwa dunia yang Allah ciptakan menyandang predikat "sungguh amat baik." Ketika kekristenan mengklaim kisah tentang Allah yang menciptakan dan menebusnya kembali, maka orang-orang percaya melalui praksisnya harus memberikan pemaknaan ciptaan baru yang subversif tentang apa yang disebut "baik." Perjuangan mengejar kebaikan bersama ini juga menjadi kesaksian orang-orang Kristen di Indonesia untuk menunjukkan apa artinya menjadi manusia sejati

81. Wright, Surprised by Hope, 253. 
(what it means to be human). ${ }^{82}$ Wright berkata, "... new creation is not a denial of our humanness, but its reaffirmation ... 183

Dengan demikian, jika panggilan Injil Yesus Kristus adalah untuk menghadirkan kerajaan Allah di bumi, pemberitaan Injil dan aksi sosial tidak pernah terpisahkan satu sama lain. Praksis ciptaan baru melihat bahwa pelayanan sosial yang dikerjakan oleh Kristus adalah perwujudan proklamasi Injil kerajaan Allah. ${ }^{84}$ Penginjilan yang hanya berfokus pada keselamatan namun tidak mampu menghubungkan antara pengampunan dosa dan gema-gema dari satu suara dalam kehidupan manusia sesungguhnya sedang mengabaikan panggilan Injil itu sendiri. Penulis melihat setidaknya dalam dimensi sosial ada tiga aspek yang bisa dikerjakan oleh orang Kristen dalam ruang publik di Indonesia, yakni kemiskinan, keadilan, dan ekologi.

Pertama praksis ciptaan baru perlu berupaya untuk mengatasi kemiskinan. Kehidupan Yesus di dunia menunjukkan dengan jelas bahwa salah satu tanda-tanda kedatangan kerajaan Allah ialah pemulihan bagi orang yang miskin, sakit maupun terlantar.

82. Wright, The Day the Revolution Began, 376.

83. Wright, Simply Christian, 190. Perjuangan ini sebetulnya juga menjadi afirmasi mutlak dari "gema-gema dari sebuah suara" (echoes of a voice).

84. Di sini Wright sendiri melihat bahwa ada ketegangan antara Injil sosial yang menekankan aksi sosial semata namun tanpa proklamasi kematian dan kebangkitan-Nya dengan Injil yang hanya memberitakan pengampunan dosa namun tanpa aksi sosial karena dianggap melegitimasi keselamatan karena perbuatan. Dalam konteks ini, praksis ciptaan baru merangkul kedua ketegangan ini (Wright, Surprised by Scripture, 170-71). 
Kristus sendiri mengidentifikasi diri-Nya dengan orang-orang yang demikian dan menuntut murid-murid-Nya untuk berbuat baik bagi mereka (Mat. 25:31-46). Injil yang diberitakan oleh Yesus selalu diikuti dengan tindakan melayani orang-orang yang membutuhkan. Di seluruh dunia, termasuk Indonesia, kesenjangan sosial selalu menggerogoti kehidupan masyarakat. Di tengah kemandekan pemerintah mengatasi masalah kemiskinan yang tak kunjung selesai, apa yang bisa dilakukan kaum injili di Indonesia?

Jika Kristus mengidentifikasi diri-Nya dengan orang-orang miskin, maka kemiskinan seharusnya tidak menjadi pelayanan "sampingan" gereja, tetapi sebagai bagian dari misi mengabarkan Injil kerajaan Allah. Ini berarti pelayanan kepada orang-orang miskin seharusnya tidak lagi bersifat insidentil dan karitatif sehingga pelayanan yang dilakukan hanya terkesan "tabrak lari" semata. ${ }^{85}$ Pelayanan sosial kepada orang-orang miskin harus kembali lagi kepada visi kerajaan Allah untuk mengembalikan panggilan manusia seperti gambar dan rupa-Nya. ${ }^{86}$ Peningkatan taraf hidup mereka

85. Institute for Community and Development Studies (ICDS) merilis sebuah survei pada tahun 2002 tentang respons gereja injili di Bandung dan Jakarta terhadap kemiskinan. Dari penelitian tersebut, peneliti ICDS menyimpulkan bahwa kendati sebagian besar (64\%) gereja-gereja injili setuju bahwa gereja perlu melakukan pelayanan sosial, pelayanan gereja pada orang miskin masih "bersifat karitatif dengan alasan mempraktikkan ajaran Alkitab" (Tim Peneliti ICDS, "Gereja dan Kemiskinan: Suatu Survei tentang Respons Gereja Kalangan Injili di Kota Jakarta dan Bandung Terhadap Masalah Kemiskinan," Jurnal Studi Pembangunan, Kemasyarakatan \& Lingkungan 4 no. 1 [2002]: 5-18).

86. Rupen Das berkata bahwa pelayanan kepada orang-orang miskin sangat bergantung kepada bagaimana orang-orang Kristen 
tidak hanya berhenti kepada aspek jasmani, tetapi juga aspek karakter, kepribadian, dan rohani. Ketika gereja mampu memerhatikan orang-orang miskin secara holistik, gereja sedang "memanusiakan manusia" dan secara tidak langsung mengajak mereka untuk kembali kepada visi Allah yang juga sedang menebus dunia materi ini. Ketika orang-orang miskin merasa diri mereka berharga di hadapan Allah dan sesama, mereka akan melihat bahwa Injil itu dinyatakan melalui kesaksian hidup orang percaya yang mereka jumpai.

Aspek yang kedua adalah masalah keadilan. Kemiskinan menjadi masalah yang tidak pernah selesai karena mereka menjadi korban ketidakadilan yang masih merajalela, baik secara individual maupun korporat. Keadilan berbicara soal dunia yang dijalankan secara benar (world being put to right). Jika Kristus adalah Raja yang memulihkan dunia, maka keadilan bukan sesuatu yang bersifat utopis, juga bukan sesuatu yang baru akan datang nanti, melainkan keadilan yang bernilai kekal karena ada di dalam dunia baru milik Allah yang dimulai oleh kebangkitan Kristus dan yang la akan genapi secara klimaks ketika la datang kembali. Ketika gereja memberi perhatian kepada ketidakadilan, gereja sebetulnya sedang

memahami millenium atau kerajaan seribu tahun, apakah itu premillenialism, postmillenialism, ataupun amillenialism. Perkataannya ini menyiratkan bahwa visi eskatologis akan sangat memengaruhi praksis hidup orang percaya. Visi itu membentuk sebuah rancangan bagaimana seharusnya seseorang bertindak (Rupen Das, Compassion and the Mission of God: Revealing the Invisible Kingdom [Carlisle: Langham, 2016], 113-15). 
menawarkan sebuah visi ciptaan baru yang Allah genapi dalam Kristus, Allah yang telah mendengar jeritan umat-Nya dalam perbudakan dan datang untuk membawa pembebasan. ${ }^{87}$ Ken Wytsma, dalam percakapan pribadinya, mendengar John M. Perkins berkata, "Preaching a gospel absent of justice is preaching no gospel at all." 188

Jalan keadilan Allah yang mendengar tangisan orang-orang tertindas tidak ditunjukkan-Nya dengan cara dunia yang membalas anarki dengan anarki. Sebaliknya, sama seperti kepada orang miskin, Kristus juga mengidentifikasi diri-Nya di atas kayu salib dengan mereka yang terpinggirkan karena la sendiri menanggung ketidakadilan dari pemerintah Roma. ${ }^{89}$ Selain itu, bukan hanya orangorang di luar gereja yang mengalami ketidakadilan. Tubuh Kristus pun menanggung ketidakadilan sebagai minoritas tapi sekaligus memulihkannya melalui kematian dan kebangkitan-Nya yang memulai ciptaan baru. Namun, justru di sinilah penulis melihat kesaksian Kristus bisa dinyatakan. Sebagai minoritas yang menjadi korban ketidakadilan, apakah justru gereja bisa tetap bergerak ke luar dan bahkan membela hak-hak orang yang tidak seiman atau bahkan musuhnya? Apakah orang-orang percaya berani berdiri bersama untuk menyuarakan keadilan, bukan hanya bagi dirinya, tapi juga bagi bangsanya?

87. Wright, Surprised by Hope, 214.

88. Ken Wytsma, Pursuing Justice: The Call to Live \& Die for Bigger Things (Nashville: Thomas Nelson, 2013), 37.

89. Wright, Simply Christian, 192-93. 
Aspek yang ketiga adalah ekologi. Jika dengan kematian dan kebangkitan Kristus Allah mengklaim kembali dunia milik-Nya, maka orang percaya kembali dipanggil untuk menjadi gambar dan rupaNya dengan melakukan penatalayanan terhadap ciptaan (stewardship of creation). ${ }^{90}$ Ruang dan materi dalam ciptaan adalah milik Allah karena penebusan yang dikerjakan Kristus adalah penebusan kosmis yang mencakup bukan hanya rintihan manusia tetapi juga ciptaan (bdk. Rm. 8:19). Pemulihan yang dikerjakan Kristus adalah rekonsiliasi antara Allah dan dunia. Dengan demikian, panggilan untuk merawat ciptaan (creation care) juga merupakan panggilan ciptaan baru karena keindahan ciptaan mencerminkan keindahan Allah. Kristus yang memulihkan relasi Allah dan ciptaan sesungguhnya sedang menjawab gema keindahan dari dalam hati setiap manusia karena la adalah keindahan ultimat itu sendiri. ${ }^{91}$

Ekologi tidak pernah berdiri sendiri, tetapi berkaitan erat dengan keadilan karena seringkali bumi dieksploitasi sedemikian rupa oleh kerakusan manusia yang pada akhirnya merenggut hak orang lain. Di Indonesia, konflik agraria sendiri masih terbilang cukup banyak dan marak. Konsorsium Pembaruan Agraria (KPA) mencatat bahwa tahun 2016 sendiri telah terjadi 450 konflik agraria dengan total wilayah 1.265 .027 hektar dan berdampak pada 86.745 orang. ${ }^{92}$

90. Richard Bauckham, The Bible and Ecology: Rediscovering the Community of Creation (Waco: Baylor University, 2010), 33.

91. Wright, Simply Christian, 200.

92. Konsorsium Pembaruan Agraria, "KPA Launching Catatan Akhir Tahun 2016," www.kpa.or.id/news/blog/kpa-launching-catatan-akhir-tahun2016/. Di Indonesia sendiri sudah ada gerakan Kristen yang bernama Kristen 
Orang percaya dapat mengambil bagian di dalamnya dari berbagai segi: menumbuhkan kesadaran di dalam gereja, mengikuti diskusidiskusi publik, atau bahkan ikut membantu advokasi bagi orangorang yang haknya diambil. Perjuangan terhadap ciptaan adalah perjuangan yang bernilai kekal karena suatu saat Allah yang sama akan mentransformasi dunia ini, bukan menghancurkannya. ${ }^{93}$ Cape Town Commitment sendiri memperlihatkan kaitan antara ciptaan dan misi Allah ini dengan sangat jelas, ${ }^{94}$

We love the world of God's creation ... it is the logical outworking of our love for God by caring for what belongs to him. "The earth is the Lord's and everything in it." The earth is the property of the God we claim to love and obey. We care for the earth, most simply, because it belongs to the one whom we call Lord ... For to proclaim the gospel that says "Jesus is Lord" is to proclaim the gospel that includes the earth, since Christ's Lordship is over all creation. Creation care is thus a gospel issue within the Lordship of Christ.

\section{Ciptaan Baru sebagai Tindakan Allah bagi Dunia dalam Diri Orang} Percaya

Seringkali penekanan teologis kepada apa yang dapat dikerjakan oleh orang percaya dianggap melegitimasi pembenaran karena perbuatan (justification by works) atau juga humanisme yang

Hijau. Jaringan organisasi ini memperjuangkan kelestarian lingkungan hidup sekaligus hak-hak orang di dalamnya lih. https://kristenhijau.wordpress.com (diakses 12 Desember 2017).

93. Wright, Surprised by Scripture, 95.

94. The Lausanne Movement, The Cape Town Commitment: A Confession of Faith and a Call to Action (Peabody: Hendrickson, 2011), 19. 
utopis. Namun, justru praksis ciptaan baru ini tidak bersumber dari manusia, melainkan dimulai, dikerjakan, dan diakhiri oleh Allah sendiri. Kitab Kisah Para Rasul sendiri menegaskan bahwa praksis hidup para rasul dan para pemberita Injil justru merupakan praksis yang dinafaskan oleh Roh Kudus saat Pentakosta. ${ }^{95}$ Pentakosta merupakan proklamasi sekaligus bukti bahwa Roh Allah hadir di dalam bait-Nya, yakni orang-orang percaya yang menjadi pertemuan surga dan bumi. Wright mengatakan, "The renewal of human lives by the Holy Spirit provides the energy through which damaged and fractured human relationships can be mended and healed." 96 Pekerjaan Allah melalui Roh Kuduslah justru yang membuat Paulus berani mengatakan bahwa "... dalam persekutuan dengan Tuhan, jerih payahmu tidak sia-sia" (1Kor. 15:58). Praksis ciptaan baru diinisiasi oleh kematian dan kebangkitan Kristus, lalu diperankan dalam dunia melalui pembaruan Roh Kudus dalam hidup orang percaya. ${ }^{97}$ Roh Allahlah yang memberdayakan (empowering) umatNya untuk menghidupi dunia yang akan datang di masa kini.

Jikalau demikian, maka misi kerajaan yang diproklamasikan dan dibawa oleh Yesus justru ingin membalikkan nilai-nilai kerajaan dunia. Salib Kristus yang diteladani oleh para martir justru

95. Luke Timothy Johnson, The Acts of the Apostles (Collegeville: Liturgical, 1993), 14.

96. Wright, Simply Christian, 115.

97. Wright sendiri menekankan bahwa yang membedakan kebajikan Kristen dari kebajikan dunia adalah bahwa pembaruan ini dikerjakan oleh dan di dalam Roh Kudus, bukan dari kekuatan manusia sendiri (Wright, After You Believe, 95). 
membuktikan bahwa kedatangan kerajaan Allah di bumi dinyatakan melalui sebuah skandal. Bagi dunia, salib adalah kebodohan dan kegagalan, tetapi justru bagi Allah salib adalah kekuatan dan hikmatNya (1Kor. 1: 23-30).

Pertanyaannya sekarang tentu kembali kepada apa yang dihadapi oleh orang percaya di Indonesia. Di manakah Allah dalam ruang publik Indonesia yang rawan konflik dan politisasi agama ini? Apakah Allah tetap berdaulat meskipun orang percaya ditindas, dimusuhi, dan dikucilkan sebagai minoritas? Wright berkata, “... the Christian church declares, as the ancient Jews did with the pagan king Cyrus, that God's Spirit is at work, whether the rulers know it or not." 98 Justru di tengah kondisi bangsa, praksis ciptaan baru menunjukkan bahwa Kristus tetaplah Sang Raja yang berdaulat atas dunia.

\section{Kesimpulan}

Sketsa yang penulis tawarkan tentu masih memiliki banyak celah untuk dikembangkan lebih lanjut. Namun, kembali kepada pertanyaan yang penting, apakah gereja injili bisa menjalankan mandat sosial maupun politiknya? Atau, dalam bahasa pemazmur, dapatkah kita menyanyikan nyanyian Tuhan di negeri orang asing (Mzm. 137:4)? Ya! Melalui kematian dan kebangkitan-Nya, Kristus telah menunjukkan bahwa Allah adalah Allah di ruang publik, Allah yang sudah menciptakan dunia, menebusnya, dan menjadikannya baru. Orang percaya yang dipersatukan dalam kematian dan

98. Wright, God in Public, 72. 
kebangkitan Kristus mampu menafaskan ciptaan baru itu di masa kini dengan pertolongan Roh Kudus. Seorang injili dapat mendoakan sekaligus mewujudkan doa yang diajarkan Yesus, "datanglah kerajaan-Mu, jadilah kehendak-Mu, di bumi seperti di surga" (Mat. $6: 10)$.

\section{Daftar Pustaka}

Adiprasetya, Joas. Mencari Dasar Bersama: Etik Global dalam Kajian Postmodernisme dan Pluralisme Agama. Jakarta: BPK Gunung Mulia, 2002.

Aritonang, Jan dan Karen Steenbrink. A History of Christianity in Indonesia. Leiden: Brill, 2008.

Banawiratma, J.B. "The Fragile Harmony of Religions in Indonesia." Exchange 27 no. 4 (Oktober 1998): 360-70.

Bartholomew, Craig G. Excellent Preaching: Proclaiming the Gospel in Its Context \& Ours. Bellingham: Lexham, 2015.

Bartholomew, Craig G. dan Mike W. Goheen. "Story and Biblical Theology." Dalam Out of Egypt: Biblical Theology and Biblical Interpretation. Diedit oleh Craig Bartholomew, Mary Healy, Karl Moller, dan Robin Parry. Grand Rapids: Zondervan, 2004.

Bauckham, Richard. The Bible and Ecology: Rediscovering the Community of Creation. Waco: Baylor University, 2010.

Bird, Michael F. The Saving Righteousness of God: Studies on Paul, Justification, and the New Perspective. Eugene: Wipf and Stock, 2007.

Breitenberg Jr., Harold E. "What Is Public Theology?" Dalam Public Theology for a Global Society: Essays in Honor of Max L. Stackhouse. Diedit oleh Deirdre King Hainsworth dan Scott R. Paeth. Grand Rapids: Eerdmans, 2010.

Budziszewski, J., ed. "Evangelicals in the Public Square." Dalam Evangelicals in the Public Square: Four Formative Voices on Political Thought and Action. Grand Rapids: Baker, 2006.

Buttelli, Felipe Gustavo Koch. "Public Theology as Theology on Kairos: The South African Kairos Document as a Model of Public 
Theology." Journal of Theology for Southern Africa 143 (Juli 201): 90-106.

Darmaputera, Eka. "Pancasila Sebagai Satu-satunya Asas dalam Kehidupan Bermasyarakat, Berbangsa dan Bernegara: Sebuah Evaluasi Ulang." Dalam Agama-agama Memasuki Milenium Ketiga. Diedit oleh Martin L. Sinaga. Jakarta: Gramedia, 2000.

Das, Rupen. Compassion and the Mission of God: Revealing the Invisible Kingdom. Carlisle: Langham, 2016.

Hainsworth, Deirdre King dan Paeth, Scott R. Public Theology for a Global Society: Essays in Honor of Max Stackhouse. Grand Rapids: Eerdmans, 2009.

Hutabarat, Binsar A. dan H. Hans Panjaitan. "Tingkat Toleransi Antaragama di Masyarakat Indonesia." Societas Dei 3 no. 1 (April 2016): 8-34.

Institute for Community and Development Studies. "Gereja dan Kemiskinan: Suatu Survei tentang Respons Gereja Kalangan Injili di Kota Jakarta dan Bandung Terhadap Masalah Kemiskinan." Jurnal Studi Pembangunan, Kemasyarakatan \& Lingkungan 4 no. 1 (2002): 5-18.

Intan, Benyamin F. "'Public Religion' and the Pancasila-Based State of Indonesia: A Theological-Ethical Analysis." Verbum Christi 1 no. 1 (April 2014): 24-41.

Johnson, Luke Timothy. The Acts of the Apostles. Collegeville: Liturgical, 1992.

Maggay, Melba Padilla. Transformasi Masyarakat: Refleksi Keterlibatan Sosial Kristen. Diterjemahkan oleh Yohannes Somawiharja. Jakarta: Cultivate, 2004.

McDermott, Gerald R. dan Harold A. Netland. A Trinitarian Theology of Religions: An Evangelical Proposal. New York: Oxford University, 2014.

Netland, Harold. Dissonant Voices: Religious Pluralism and the Question of Truth. Grand Rapids: Eerdmans, 1991. . Encountering Religious Pluralism: Tantangan bagi Iman dan Misi Kristen. Diterjemahkan oleh Selviya Hanna. Malang: Literatur SAAT, 2015. 
O'Donovan, Oliver. The Desire of the Nations: Rediscovering the Roots of Political Theology. Cambridge: Cambridge University, 1996.

Packer, J.I. dan Thomas Oden. Satu Iman: Konsensus Injili. Jakarta: BPK Gunung Mulia, 2011.

Riyanto, Armand. Dialog Interreligius: Historisitas, Tesis, Pergumulan, Wajah. Yogyakarta: Kanisius 2010.

Schreiner, Thomas. "Justification: The Saving Righteousness of God in Christ." JETS 54 no. 1 (Maret 2011): 19-34.

Second Lausanne International Congress on World Evangelization. "The Manila Manifesto (Excerpt)." International Bullletin of Missionary Research 13 no. 4 (Oktober 1989): 164-166.

Smith, James K.A. "The Reformed (Transformationist) View." Dalam Five Views on Church and Politics. Counterpoints: Biblical theology. Diedit oleh Amy E. Black. Grand Rapids: Zondervan, 2015.

. Awaiting the King: Reforming Public Theology. Cultural Liturgies 3. Grand Rapids: Baker, 2017.

Stackhouse Jr., John G. Making the Best of It: Following Christ in the Real World. Oxford: Oxford University, 2011.

Sotrkey, Alan. Jesus and Politics: Confronting the Powers. Grand Rapids: Baker, 2005.

Strange, Daniel. "Evangelical Public Theology: What on Earth? Why on Earth? How on Earth?" Dalam A Higher Throne: Evangelicals and Public Theology. Diedit oleh Chris Green. Nottingham: Apollos, 2008.

. "Not Ashamed!: The Sufficiency of Scripture for Public Theology." Themelios 36 no. 2 (2011): 238-60.

Stott, John. New Issues Facing Christians Today. Edisi revisi. London: Marshall Pickering, 1990.

The Lausanne Movement. The Cape Town Commitment: A Confession

of Faith and A Call to Action. Peabody: Hendrickson, 2011.

Vanhoozer, Kevin J. Drama Doktrin: Suatu Pendekatan KanonikLinguistik pada Teologi Kristen. Diterjemahkan oleh Satya Limanta. Surabaya: Momentum, 2007. 
. Pictures at Theological Exhibition: Scenes of Church's Worship, Witness, and Wisdom. Downers Grove: InterVarsity, 2016.

Volf, Miroslav. Exclusion \& Embrace: Theological Exploration of Identity, Otherness, and Reconciliation. Nashville: Abingdon, 1996.

. Public Faith: How Followers of Christ should Serve the Common Good. Grand Rapids: Brazos, 2011.

Walsh, Brian J. Subversive Christianity: Imaging God in A Dangerous Time. Edisi kedua. Eugene: Wipf and Stock, 2014.

Wright, N.T. After You Believe: Why Christian Character Matters. New York: HarperCollins, 2010.

. Christian Origins and the Question of God, vol. 1 dari New Testament and the People of God. Minneapolis: Fortress, 1992.

. Christian Origins and the Question of God, vol. 2 dari Jesus and the Victory of God. Minneapolis: Fortress, 1996.

. Christian Origins and the Question of God, vol. 3 dari The Resurrection of the Son of God. Minneapolis: Fortress, 2003.

. Christian Origins and the Question of God, vol. 4 dari Paul and the Faithfulness of God. Minneapolis: Fortress, 2013.

. Evil and the Justice of God. London: SPCK, 2006.

. How God Became King: The Forgotten Story of the Gospels. New York: HarperCollins, 2012.

. God in Public: How the Bible Speaks Truth to Power Today. London: SPCK, 2016.

. "Paul's Gospels and Caesar's Empire." Dalam Paul and Politics: Ekklesia, Israel, Imperium, Interpretation. Diedit oleh Richard A. Horsley. Harrisburg: Trinity, 2000.

. Simply Christian: Why Christianity Makes Sense. New York: HarperCollins, 2006.

. Surprised by Hope: Rethinking Heaven, Resurrection, and the Mission of the Church. New York: HarperCollins, 2008.

. Surprised by Scripture: Engaging Contemporary Issues. New York: HarperCollins, 2014.

. The Day the Revolution Began: Rethinking the Meaning of Jesus' Crucifixion. London: SPCK, 2016. 
Wytsma, Ken. Pursuing Justice: The Call to Live \& Die for Bigger Things. Nashville: Thomas Nelson, 2013.

Yewangoe, Andreas A. Tidak Ada Ghetto: Gereja di dalam Dunia. Jakarta: BPK Gunung Mulia, 2009.

Yosia, Adrianus. "Mendramakan Doktrin sebagai Bentuk Partisipasi Kaum Injili pada Dialog Antar-Iman di Indonesia." Skripsi M.Div. STT SAAT, 2017.

Zabatiero, Júlio Paulo Tavares. "From Sacristy to the Public Square: The Public Character of Theology." International Journal of Public Theology 6 (2012): 56-69.

Internet

Konsorsium Pembaruan Agraria, "KPA Launching Catatan Akhir Tahun 2016." Konsorsium Pembaruan Agraria. www.kpa.or.id/news/blog/kpa-launching-catatan-akhirtahun-2016/ (Diakses 12 Desember 2017). 